\title{
Application of Organic Waste Compost in Seyhan Region
}

\author{
Akif Kemal Akay, Burcu Ak Çimen, Semih Sayinta
}

\section{ABSTRACT}

In this study aims to recycle farmers market and garden waste into compost and bring it back to soil as a useful and valuable organic fertilizer thanks to natural processes in Seyhan Region. With the compost production, it is aimed to promote both soil improvement and organic fertilizer use and recycling. The compost has many benefits for agricultural activities. This review, the main challenges of the process of organic waste compost and explores the crucial aspects related to the quality of the produced the importance of compost. Although the importance of compost production is known, the importance of composting and more information are needed. Therefore, in this study, innovative approaches with different methods have been investigated. Environmental and biodiversity impacts related to organic waste composting detailed in this study. This study investigated the application of blue-green algae to enhance the quality of composts composed from multiple organic waste. This research provides an innovative method for using algae the compost products. The importance of using algae in order to achieve rapid results in innovative and sustainable agriculture areas in composting was explained. A pilot project application was established to optimize organic waste collection and composting for agriculture in Compost Production facility in Seyhan Municipality. In addition, also in this study contributed to the environmental and biodiversity awareness and zero waste projects research of applicability. Studying areas should be created for composting in municipalities.

Keywords: Compost, composting parameters, process, agriculture, Seyhan Region, municipalities.

\author{
Submitted : February 8, 2021 \\ Published : February 22, 2021 \\ ISSN: 2684-1827 \\ DOI: $10.24018 /$ ejfood.2021.3.1.240
}

\section{Akif Kemal Akay}

Seyhan Municipality of Mayor, Adana, Turkey.

Burcu Ak Çimen*

Seyhan Municipality, Adana, Turkey.

(e-mail: bak@cu.edu.tr)

Semih Sayinta

Seyhan Municipality, Adana, Turkey.

*Corresponding Author

\section{INTRODUCTION}

Economic conditions and intense demand for technology that change due to rapid urbanization and increasing human population have affected all over the world as well as causing ecocide in Turkey in a negative way and have led to serious environmental damage. Therefore, economic growth and rising food consumption in the world have led to increased production of organic wastes due to an important condensation of the agricultural production systems. Solid waste, which has an important share in environmental pollution, has become an important problem that the world authorities emphasize today. Turning solid wastes into an environmentally sound structure; in other words, recycling wastes into a balanced product and reusing them in nature are among the primary targets of integrated waste management.

Composting is simply biological process, the enhancement of the e natural biological transformation of organic matter. Microorganisms convert the organic matter into organic fertilizer as material humus-like material; the end product being more commonly known as compost. Composting consists of under aerobic conditions, with sufficient moisture and temperature which can be metabolic processes performed by different microorganisms that, in the presence of oxygen, use nitrogen $(\mathrm{N})$ and carbon $(\mathrm{C})$ available to produce their own biomass [1]-[3].

In this context, this review aims to recycle farmers market and garden waste into compost and bring it back to soil as a useful and valuable organic fertilizer thanks to natural processes. With the compost production, it is aimed to promote both soil improvement and organic fertilizer use and recycling. Inappropriate disinfect and excessive use of chemical fertilizers pose a threat to nature and groundwater resources, making it difficult to take products by inefficient soil. By producing compost aims to evaluate organic wastes, improve the structure and aeration of the soil, neutralize toxins, provide nutrients when plants need it, and strengthen the plant by accelerating growth [4]. The compost has many benefits for agricultural activities. Because of these features' generation and application of good quality composting products are highly desired. The public should be informed about this issue and encouraged to produce.

This review, the main challenges of the process of organic waste compost and investigate the important aspects concerned to the quality of the produced the importance of 
compost. Although recent advances have been accomplished in critical aspects of the compost process, the importance of composting and more information are needed. Therefore, in this study, it has been compilated in order to generally inform the importance of organic waste compost production. In addition, environmental impacts related to organic waste composting detailed in this review. At the same time, this research investigated the application of blue-green algae to enhance the quality of composts composed from multiple organic waste. The using algae in the composting process creates a more environmentally friendly option for the organic waste stream management [4]. In this context, a pilot project application was established to optimize organic waste collection and composting for agriculture in Compost Production Facility in Seyhan Municipality. In this case, studying areas should be created for composting in municipalities.

\section{Why compost is important?}

Biological diversity includes plants, animals, ecosystems and habitats. Biodiversity is one of the most essential elements for continuing life on Earth. However, a continuous biodiversity that affects natural life and human well-being is rapidly disappearing. Changes in natural habitats due to intensive agricultural production systems, construction, quarry activities, forests, oceans, rivers, lakes and soil overuse, climate change, excessive increase in air pollution rate and spread of diseases, pollution, increasing global climate change accelerates the disappearance of biodiversity. The great role played by biodiversity in the sustainability of our world and lives makes its ongoing loss more and more unsettling [5], [6].

According to the researches, human population is expected to reach 9 billion by 2050. Increasing in the human population will reveal the incredible loss of overconsumption, climate change and biodiversity. Therefore, we need to take measures to slow or stop biodiversity decline.

The concept of "green growth" come into prominence with the search for a new growth model that initiated on a global scale in order to achieve sustainable development goals. Within the framework of this concept, it is possible to protect both the environment and increase competitiveness with clean production and eco-efficiency in the production sectors, ecological potential is evaluated in environmentally sensitive sectors such as agriculture and tourism, and it is emphasized that cities can be more environmentally friendly and economically effective with new regulations and investments. Within this scope, priority is given to the efforts to prevent pollution, conservation of biological diversity and natural resources and its sustainable use [7]. Turkey has the potential to transform environmental challenges into opportunities with environmental decisions and projects.

Increasing urbanization rate caused an increase in the amount of domestic waste and change in its composition. This created a problem that was difficult to control. On the other hand, it has turned into a great economic value.

Approximately 3800-4000 tons of domestic waste is generated daily in Adana. Approximately 2500 tons of this waste is disposed at licensed facilities in Adana. However, the remaining 1500 tons of waste is left to the nature by uncontrolled disposal of waste. In other words, 540 thousand tons of urban waste accumulates in open land in unhealthy conditions every year. This poses a great threat to human health and nature. In terms of economy, the opportunity cost of storing wastes is quite high, considering that an installed power of over $10 \mathrm{MW}$ is produced from 1500 tons of domestic waste per day in Adana and that 300 tons of uncontrolled disposal of waste can be recycled per day. The Ministry of Environment and Urbanization aims to close uncontrolled disposal of waste areas by 2023 in the Climate Change Action Plan. Garbage dump site in Adana and Mersin city centers, which have been uncontrolled disposal of waste for many years, have been rehabilitated. These studies are among the examples of good practice in Turkey. Other irregular storage areas in the region should also be closed as soon as possible and a regular storage system should be implemented.

According to Municipal Law No. 5393, it is the responsibility of the district municipalities to collect solid waste and transport it to disposal facilities or transfer stations. Therefore, Seyhan Municipality generates urban wastes of organic origin every day in the Seyhan district of Adana and aims to be used for multi-purpose purposes, especially for the improvement of agriculture and forest areas by transforming these wastes into compost.

With compost, vegetables and fruits can be grown by natural methods, eliminating the need to use medicines for your soil. In addition, the soil enriched with compost retains more water. This feature, which is very important for dry summers, will enable natural resources to gain.

On average, 2,000 tons of domestic solid waste collected from residential and commercial institutions is brought to Integrated Solid Waste Disposal Facility by 15 district municipalities of Adana. Approximately 1 in 3 of domestic waste could been composted, so it can be saved from being garbage. In this way, the density and methane emissions in the waste sites are reduced and you increase your air quality. Thus, the valuable materials you leave out of your home every day are saved from being garbage.

According to the researches, $40 \%$ of the waste coming from the residential areas comes from organic materials, $42 \%$ from recyclable sources, and $18 \%$ from other sources. According to these studies, it is understood that we should support composting and recycling. In this case, the carbon footprint will be reduced when producing compost.

People will be able to grow healthy fruit and vegetables with their organic fertilizers on the balconies of their homes. Another benefit of compost is that it provides the opportunity to function microscopic organisms and bacteria. In this way, less disease and insects are seen in the growing plants. This will also mean that you use less pesticides.

The amount and contents of the waste produced reach threatening levels. When soluble biological organic wastes (bio-wastes) are sent to solid waste landfills, as a result of natural degradation, it releases methane, a large amount of greenhouse gases, which will lead to soil and groundwater pollution. Methane $\left(\mathrm{CH}_{4}\right)$ is the most important of greenhouse gases other than carbon dioxide and is as effective as greenhouse gases other than all other carbon dioxide in global warming [8].

Organic matter rate in wastes is high in turkey, which is developing country. According to studies, a total of $698,430.78$ tons / year municipal waste was disposed in 15 
districts in Adana in 2018. The average amount of solid waste collected in Seyhan Municipality in Seyhan district of Adana is 773.32 tons / day in summer and 747.99 tons / day in winter. Seyhan Municipality Cleaning Affairs Directorate, responsible for collecting and transporting wastes in Seyhan, which has a population of 764,714 , has spent a 32.5 million TL in 2012. This expense corresponds to $18.5 \%$ of the total budget of the municipality, in other words, a budget close to 1 in 5 of revenues is reserved only for environmental services.

Every autumn season, tons of leaves of the hundreds of thousands of trees dry up and fall on the ground. The municipalities spend billions of moneys to clean up spilled leaves. Unfortunately, there is not environmentalist association and civil society organization to collect leaves spilled on the ground in Turkey.

Kitchen waste is 65 percent of the domestic waste in Seyhan Region. Plastic wastes constitute about 8 percent, glass wastes constitute 1.9 percent and paper wastes constitute 2.4 percent of municipal waste. Metal derivatives are around 2.5 per thousand. Other wastes consisting of rubber, leather, textile, ash, stone and soil make up 23 percent of all municipal waste. Composting even a small part of these wastes from not going to solid waste landfills makes a great impact on environmental protection and global climate change. According to Turkish Statistical İnstitute data, in 2013 the majority of methane emissions in Turkey (58\%) was due to the disposal of waste. The EU Landfill Directive (1999/31/CE) requires that bio-waste amount be reduced by $65 \%$ by 2016 compared to 1995 levels. Compost communique, which came into force in Turkey in 2015, requires all municipalities to separate the bio- waste without being sent to landfills. However, there is a large lack of information about composting on logistics, operations and financial sustainability [9].

Solid waste storage areas create ideal conditions for methane formation due to the large amount of organic matter and anaerobic conditions there. Methane may appear there even after the plant has been shut down due to the gradual decay of large quantities of waste buried in these areas under the ground.

Organic wastes contain of lipid, protein, carbohydrate, cellulose, hemicellulose, and they do not contain methane gas. Methane is released only when organic waste is placed in an anaerobic environment. Although compost is not entirely aerobic, it produces zero or very little methane [10]. In the composting processes carried out by the municipalities, green waste collected from food waste and gardens is separated on site and sent to compost facilities. Afterwards, cut grass and pruned wood pieces collected from food waste and gardens are crushed to $400 \mathrm{~mm}$ in size and mixed with some compost activator containing micro-organisms and enzymes to ensure effective composting. It turns into compost that can be used as fertilizer depending on the humidity and air temperature in bio-wastes.

Compost not only helps combat global climate change, but it also prevents leakage in landfills, saves land from being used for solid waste storage and provides green fields employment. Bio-wastes going to landfills and waste storage lead to the emergence of methane gas, which increases climate change. Transport of bio-waste has a major ecological footprint. They contaminate the soil and water with leachate waters and use lands that would otherwise be empty.

Compost is extremely useful for poor quality soils. According to the United States Department of Agriculture research, the use of compost reduces fertilizer needs by at least $20 \%$, significantly reducing net greenhouse gas emissions. Compost can significantly strengthen the physical structure of the soil. In fine textured (clayey and sandy) soils, adding compost reduces the bulk density, improves soil workability and pore texture and increases water and gas permeability. Thus, the probability of erosion is reduced. When used in sufficient quantities, compost has a positive effect on soil structure both in the short and long term. It can increase drought resistance and provide more efficient water use. Thus, the frequency and intensity of irrigation can be reduced. Research also suggests that adding compost to sandy soils can facilitate moisture distribution by allowing water to move sideways from the irrigation point. Adding compost to the soil fixes the $\mathrm{pH}$ value in the soil; thus, the soil becomes more resistant to $\mathrm{pH}$ change [11]. Because of these reasons will contribute to improve the soil with climate change, pollution, biodiversity and environmental status of Turkey's development by converting agricultural wastes into compost.

\section{MATERIAL AND METHOD}

Compost is prepared directly in a pile or in a cage of wood, wire or other materials [12], [13].

The materials in hand are laid on top of each other in layers of $5-10 \mathrm{~cm}$, forming approximately $1 \mathrm{~m}^{3}$. For a $1 \mathrm{~m}^{3}$ pile, it is necessary to create a circle base with a diameter of about 1.5 meters and raise it by 1.5 meters. One layer of carboncontaining material, one layer of nitrogen-containing material, and in between, ash, rock dust, coal and other accelerators / enhancers are sprinkled. Each layer is irrigated slightly to provide the appropriate moisture content. Especially accelerators such as algae, urea, dead nettle should be placed in the middle of the pile when the compost rises to half. The compost layers are shown in Table 1.

\begin{tabular}{ccc}
\multicolumn{3}{c}{ TABLE 1: THE COMPOST LAYERS } \\
\hline Outer Layer & Carbon & $5-10 \mathrm{~cm}$ \\
& Nitrogen & $5-10 \mathrm{~cm}$ \\
3rd layer & Carbon & $5-10 \mathrm{~cm}$ \\
& Nitrogen & $5-10 \mathrm{~cm}$ \\
2nd layer & Carbon & $5-10 \mathrm{~cm}$ \\
& Nitrogen & $5-10 \mathrm{~cm}$ \\
1st layer & Carbon & $5-10 \mathrm{~cm}$ \\
\hline
\end{tabular}

The hot compost pile needs to be turned upside down for the ideal amount of aeration and mixing. What is meant by turning is to tip the pile with the help of a pitchfork and a shovel so that the outer parts are in and the inner parts are out. During the turning process, it is aimed that the materials that were previously spread in layers are mixed together homogeneously [14], [15]. The compost pile process shown in Fig. 1. 


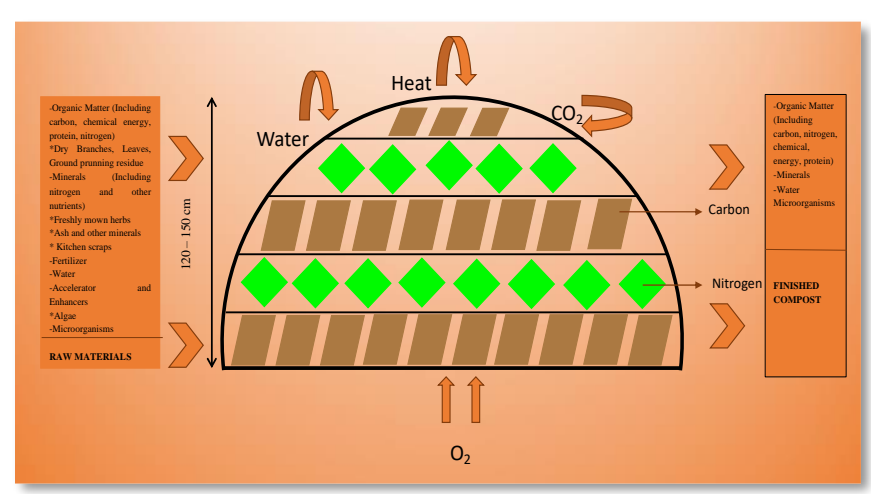

Fig. 1. The compost pile process.

The aim of turning the compost pile is to provide opportunity to moisturize, warmth, to allow cooling down overheated pile and air ventilation.

It is shaped according to the $\mathrm{C} / \mathrm{N}$ and humidity ratio of the prepared mixture. Ideally, it's turned upside down on 4., 6., 8., 10., 12., 14., 16. and 18. days [14]. Compost is completed at the end of this process. Materials required for hot compost production are shown in Table 2. Temperature and mixing are very important in the composting process (Fig. 2).

Temperature and mixing are very important in the composting process (Fig. 2). Compost models produced in Seyhan Municipality are shown in Fig. 3.

TABLE 2: ReQuired MATERIALS FOR A SAMPLE Hot Compost Pile Dry, carbon-containing material

Straw, dry leaves, milled branches, sawdust, grain bran, etc. only or mixed

15 sacks

Animal fertilizer

Cow, sheep, goat, alone or mixed.

Chicken manure can be used by diluting

a small amount.

Kitchen food waste

If it is not possible to collect that much waste in one go, wait for use while the pile is being prepared.

Freshly mown herbs

Herbs that have not reached the seed stage are preferred. It is useful to wait 1-

2 days after the herbs are cut.

Wooden ash

Provides mineral content

Water

Accelerators

Algae, nettle, diluted urine, urea and any material with a high nitrogen content. Depending on the $\mathrm{C}$ and $\mathrm{N}$ ratio, in waste such as straw, up to $1 \mathrm{~kg}$ of nitrogen fertilizer for $100 \mathrm{~kg}$ of straw can accelerate the process.

Enhancers

Mineral rich material such as easily available volcanic rock dust, seaweed, charcoal, comfrey.

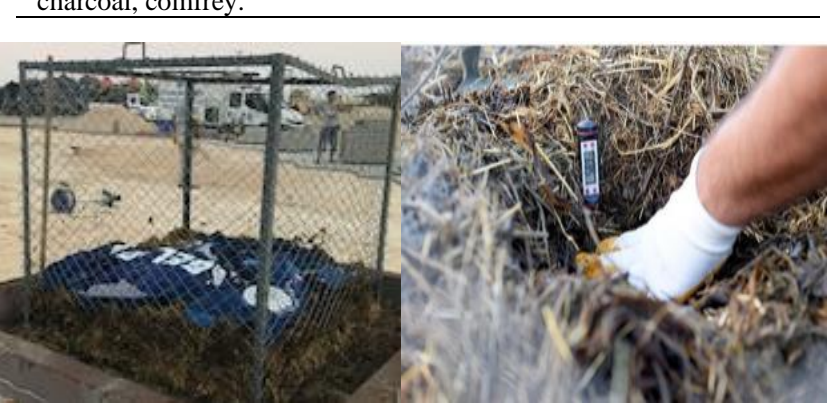

Fig. 2. Composting production and process.

A few bucketful How much you have

5 sacks

$$
5 \mathrm{~kg}
$$
the moisture content

About 1-2 buckets

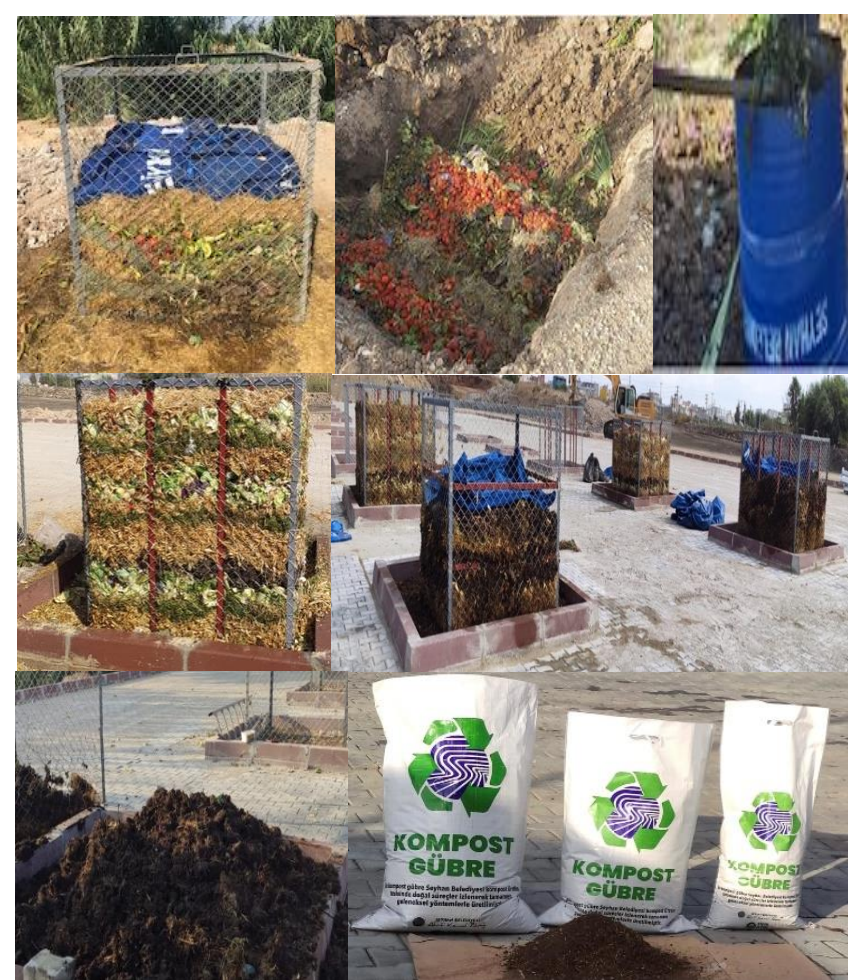

Fig. 3. Compost models produced in Seyhan Municipality.

\section{RESULTS AND DISCUSSION}

Compost, which can be used as an organic fertilizer to enrich the soil in organic matter, was produced in the Seyhan Municipality "Compost Production Facility" by mixing in the wastes from parks and garden, pruning and market waste. The general nutritional components of the produced compost are presented in Table 3.

Just enough to provide

TABLE 3: NUTRITIONAL COMPONENT OF COMPOST $\begin{array}{cc}\text { Component } & \text { W/W } \\ \text { Total organic matter } & 45 \%\end{array}$

Total N $(\%) \quad 1.96 \%$

Total $\mathrm{P}\left(\mathrm{P}_{2} \mathrm{O}_{5}\right) \quad 0.14 \%$

Total $\mathrm{K}\left(\mathrm{K}_{2} \mathrm{O}\right)$

Total Calcium oxide $(\mathrm{CaO}) \quad 0.5 \%$

$\mathrm{Mg}(\mathrm{ppm})$

$\mathrm{Na}(\mathrm{ppm}) \quad 502.42$

$\mathrm{Fe}(\mathrm{ppm}) \quad 6980$

$\mathrm{Zn}(\mathrm{ppm}) \quad 33.89$

$\mathrm{Cu}(\mathrm{ppm}) \quad 7.78$

$\mathrm{Mn}(\mathrm{ppm})$

$\mathrm{pH} \quad 8.42$

Maximum humidity $15 \%$

\section{A. Composting Parameters}

The parameters affecting the compost formation process speed and compost quality are particle size, $\mathrm{C} / \mathrm{N}$ ratio, moisture content, mixing, temperature, ventilation, and $\mathrm{pH}$ [3].

\section{Particle size}

Since microbial activity occurs on the surface of organic materials, it improves microbial activity and biochemical reaction rate throughout the aerobic composting process due to the reduction of particle size and increased surface area. On the other hand, the fact that the particles are very small prevents air circulation in the composting pile and reduces the oxygen and microbial activity needed by the microorganism. 
For these reasons, the preferred particle size in the composting process is less than $5 \mathrm{~cm}$ [16].

\section{C/N ratio}

The development of the activities of microorganisms in the process depends on the $\mathrm{C}$ and $\mathrm{N}$ content. Microorganisms use carbon as the energy source, whereas nitrogen is the basic component of protein, nucleic acid, amino acid, and enzymes required for cell growth and function and increases the growth rate of microorganisms [3]. If the amount of nitrogen is limited, the microorganism population decreases, and the carbon dissociation takes a long time [16]. The ratio of nitrogen and carbon contained in vegetable wastes to the composition of the compost is very important in order to meet the nutrient needs of microorganisms that play an active role in decomposition. This is because the $\mathrm{C} / \mathrm{N}$ ratios lower than the desired values (approximately 30/1) turn into ammonia gas of nitrogen, which will be found more than necessary in the environment, leaving the environment by causing unwanted odors [3]. Increases in $\mathrm{C} / \mathrm{N}$ ratio are associated with ammonia loss during composting. In this case, the fragmentation continues at a lower rate since the nitrogen required by the microbial activity in the environment cannot be found [17]. The optimum $\mathrm{C} / \mathrm{N}$ ratio should be 25-30. Otherwise, microbial activities will slow down. At the end of the experimental studies, it was seen that a good quality product was obtained when the $\mathrm{C} / \mathrm{N}$ ratio was $15-20$ [18].

\section{Moisture content}

Moisture is essential for the growth and reproduction of microorganisms in the composting process. Organisms that carry out biochemical degradation can only get their nutrients if they are dissolved in water, so water must be present in the environment. Moisture content should be kept between 40$60 \%$ during the composting process [19]. In another study, the moisture content was below $30 \%$, the decomposition rate was rapidly decreasing; above $70 \%$, due to the was slowing of microbial activity, it caused odor formation and nutrient mixing into the filtrate water [3]. In addition, the moisture content of the waste in the reactor is an important parameter for continuity of microbial activity and good composting [20]. Substances with higher nitrogen content are wetter and substances with higher carbon content are drier. With the appropriate mixture of these different properties, easy-tocrumble compost is obtained [3].

\section{Mixing}

In order to provide a more regular and homogeneous distribution of nutrients and microorganisms, mixing is applied throughout the composting process [21]. Mixing organic solid wastes is important for keeping the moisture content, waste characteristics and air requirements at an optimum level [16].

\section{Temperature}

Temperature is one of the important factors affecting microbial activity in composting [22]. The temperature increase observed in solid wastes during the composting process occurs with exothermic reactions related to respiratory metabolism [16]. Rising temperatures accelerate the breakdown of carbohydrates such as protein, fat and cellulose [3]. However, extremely high temperatures prevent microorganisms from breaking down organic matter. The temperature distribution is affected by compost pile moisture content, ventilation rate, atmospheric conditions and $\mathrm{C} / \mathrm{N}$ ratio [22]. In composting performed in systems with air flow, the temperature can be regulated by mixing and ventilation [16].

\section{Ventilation}

Ventilation is also an important factor during composting. Ventilation is applied to provide oxygen demand for biodegradation, to remove excess moisture from the environment and to control the temperature in the process [19]. If the ventilation rate is insufficient, the amount of oxygen decreases during the composting period and the living things begin to breathe without oxygen. On the other hand, if the ventilation rate is high, the compost pile cannot be heated, and composting cannot be performed [23].

\section{7. $p H$}

Literature studies show that as long as the compost formation process is carried out under aerobic conditions, there is not $\mathrm{pH}$ control problem. However, $\mathrm{pH}$ is an important process evaluation parameter during decomposition. To ensure optimum decomposition, $\mathrm{pH}$ should remain around 7 and 7.5. The $\mathrm{pH}$ value should not exceed 8.5 to minimize the loss of nitrogen leaving the medium in the form of ammonia gas [16]. When compost is used as a soil improver, it is desirable that the soil / compost mixture $\mathrm{pH}$ is between 6.5 and $7.5[3]$.

\section{B. Modeling of Organic Waste Composting Process}

Organic waste management strategies in include waste layers and modernizing standards and technology for composting. This research on the use of blue-green algae (Spirulina platensis) to enhance the chemical qualities of municipal organic waste compost has been contributed to waste management strategies [4]. This is also an innovative approach to improving compost as a fertilizer adjustment to increase biogas production. Spirulina platensis is algae contains $60 \%$ to $70 \%$ protein, $20 \%$ carbohydrate, $5 \%$ lipid, 3 to $6 \%$ moisture, is rich in vitamin $\mathrm{A}, \mathrm{B} 12, \mathrm{E}, \mathrm{C}$, gamma linoleic acid and a source of minerals nitrogen, carbon, phosphorus, calcium and iron, is rich in chlorophyll $a$ and phycocyanin pigments, and is used as an essential nutrition support [24]-[26].

\section{Implications of Key Ingredients on Organic Waste Composting Performance Using Algae}

One innovative approach to converting organic waste into compost is to treat it with blue-green algae or seaweed [4]. These photosynthetic algae have a high carbon, protein, protein, vitamins, fatty acids, carbohydrates, minerals and pigments, hydrocarbons, polysaccharides, soluble sugars, antibiotics, and for other metabolites, glycogen, which can occupy half of the cellular area. The non-radioactive carbon in the algae cell is a water-soluble polysaccharide. It can divide into simpler carbon compounds to produce energy in the cell [4].

Algae are not only a high carbon source but also a source of nitrogen. In recent years, an increasing interest algae application of in compost production was noticed due to the accumulation of cells metabolites in large amounts because of along with being a source of nitrogen, carbon and phosphorus their biodegradation ability and rapid growth characteristic. Also, algae are used for various purposes mainly as food supplement, medicine, cosmetics, fertilizer for improving soil structure, in animal feed. 
Algae fix the nitrogen through structures called heterocysts. Atmospheric nitrogen cells convert them to amino acids by their transport. Heavy metals can be removed from the environment by chemisorption [27]-[29]. Thanks to valuable metabolites in the cell, algae are also capable of polycyclic aromatic hydrocarbon bioremediation [30], [31]. Algae contains lipids and the common glycolipid which can emulsified in the bioremediation process [32].

According to researcher biodegradation is a bio-chemical process, that is chemicals are biologically reduced. Organic (C, N, P, S, and other elements) compounds are converted into inorganic $\left(\mathrm{CO}_{2}\right.$ or inorganic forms of $\left.\mathrm{N}, \mathrm{P}, \mathrm{S}\right)$ products by the organisms in this process and then released into the surrounding as an enviromentally friendly [33].

This review provides investigate for how blue-green algae can be used to enhance the chemical composition of organic waste compost.

\section{Organic Wastes Used in Composting}

Due to the advancement of technology and the increase in the population and consequently consumption, the amount of solid waste that is released daily per capita has increased, especially in big cities. The use of wastes in composting is of great importance both in terms of contributing to the economy and preventing environmental pollution [34]. Compost: it also has a commercial value that can be sold under names such as organic fertilizers, soil improvers and growing media. All these benefits that can be obtained with compost can only be achieved through a controlled and successful composting process. For successful composting, the waste to be used in the process is of great importance in terms of the nutrients it contains. Therefore, agricultural waste will be used in the Seyhan region. 30 stainless wire cages with a length of 1.5 meters will be used for compost production. It is aimed to produce 1 ton of organic fertilizer from each unit from the composting units. There are 30 units in the Compost Production Facility in Seyhan Region (Fig. 4). In other words, 30 tons of organic fertilizer production is targeted at the end of hot compost production. Thus, cages can be used again for sustainable organic fertilizer production.

Compost generally shows values close to or above farm fertilizer. On average, in field applications, it can be given around 10 tons per decare and this amount corresponds to $150-200 \mathrm{~kg}$ of compound fertilizer. Nowadays the use of soilless or partial soil development environments has become quite common, in vegetable, ornamental plants, nursery and even dwarf fruit growing.

\section{E. Compost Application in Agriculture}

Economical, environmentally friendly and yield enhancing compost is another aspect that should be taken into consideration as an alternative or support material for many development environments.

Compost can be used as a soil conditioner due to its features such as containing essential plant nutrients like N, P and $\mathrm{K}$, also micro plant nutrients such as $\mathrm{Cu}, \mathrm{Fe}$ and $\mathrm{Zn}$ along with providing better soil aeration and better water holding capacity [3]. This research will be an example of how natural agents can be used to produce biotechnological products, in this case how a blue-green algae bloom, raising awareness and protection of biodiversity and environmental, can be used to improve organic waste compost for agricultural use. This research indicates that how to solve environmental problem (algae bloom etc.) in order to prevent the explosion of algae in nature can be used as a biotechnology to algae will affect increasing of generate a valuable agricultural compost and accelerate the production process.
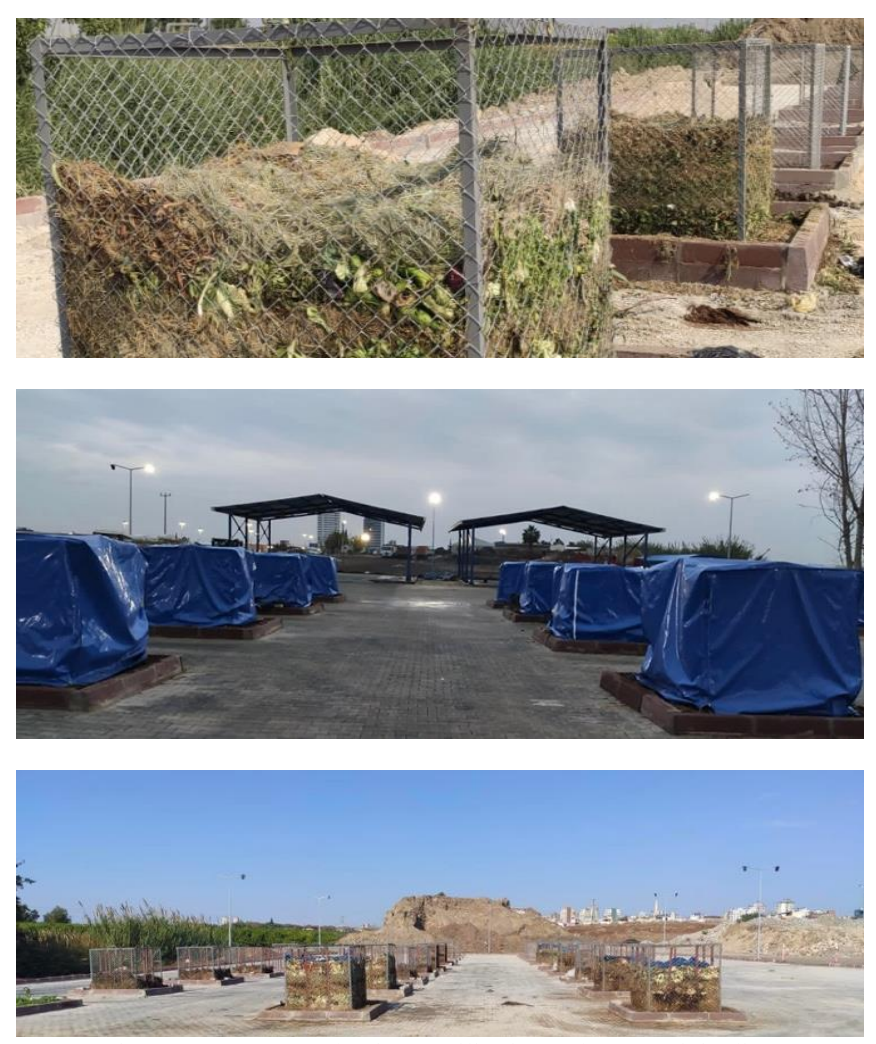

Fig. 4. Compost Production Facility in Seyhan Municipality.

\section{CONCLUSION}

As will be shown from this research project, the organic waste compost that will be chemically improved and enhanced using blue-green algae can be used as an agricultural recruitment to increase the biofuel productivity from terrestrial plants. This will help the Waste Management Facility to manage and make use of the high and accelerate quantities of organic waste compost. This way, the organic waste compost will be better conducted and lead to decreased possible health risk from airborne dusts and extended compost stench.

Meanwhile, the reuse of a wide variety of resources approaches another environmentally friendly and zero waste awareness way for organic waste management and recycling. Decomposition of algae improved the chemical properties and quality of such as $\mathrm{C}: \mathrm{N}$ and organic matter content of the compost product thanks to valuable metabolites algae in the cell. Recently, algae increasing use of in compost production because of their biodegradation ability and rapid growth characteristic.

Compost will contribute to improve the soil with climate change, pollution, biodiversity and environmental status of Turkey's development by converting agricultural wastes. While compost is extremely beneficial, such studies need to be increased. It is very important to use algae as an accelerator and enrichment. This multi-disciplinary research work will build a diverse network of academic, municipalities, government, and entrepreneur partners. Pilot projects are very 
important in terms of awareness and raising of compost projects. It is also very important for industrial and sustainable agriculture. It will be of use to as an example for future projects in order to investigate the environmental awareness and applicability of zero waste projects today. In this context, the zero-waste project effectuated that emerged as a waste management process, predictions the most efficient use of resources by preventing waste or minimizing the amount of waste. For the sustainability of this study was aimed to the compost production by providing appropriate resources and thus this study effects become widespread, and more people benefit from this practiced. Studying areas should be created for composting in municipalities.

\section{ACKNOWLEDGEMENTS}

The authors would like to thank to Dr. Berken Cimen for the instrumental analysis and critic read of the manuscript.

\section{REFERENCES}

[1] P. Roman, M.M. Martinez and A. Pantoja, "Farmer's Compost", Handbook: Experiences in Latin America. FAO Rome, (2015).

[2] K. Azim, S. Komenane and B. Soudi, "Agro-environmental assessment of composting plants in southwestern of Morocco (Souss-Massa region)", Int J Recycl Org Waste Agricult., 2017.

[3] K. Azim, B. Soudi, S. Boukhari, C. Perissol, S. Roussos and I. Thami Alami I, "Composting parameters and compost quality: A literature review”, Org Agric 8:141-158, 2018, https://doi.org/10.1007/s13165$017-0180-z$

[4] Y. Wang and T. Husain, "Use of Blue-Green Algae to Improve the Chemical Quality of Municipal Solid Waste Compost", Research Report. Memorial University of Newfoundland, St. John's, Newfoundland, 2015.

[5] J. Martínez-Blanco, C. Lazcano, T.H. Christensen, P. Muñoz, J. Rieradevall, J. Møller, A. Antón and A. Boldrin, "Compost benefits for agriculture evaluated by life cycle assessment. A review”, Agron Sustain Dev 33(4):721-732, 2013, doi:10.1007/s13593-013-0148-7.

[6] I. Kowarik, L. K. Fischer and D. Kendal, "Biodiversity Conservation and Sustainable Urban Development. Sustainability”, 12, 4964, 2020.

[7] I. Otero, K.N. Farrell, S. Pueyo, G. Kallis, L. Kehoe, H. Haberl, C. Plutzar, P. Hobson, J. García-Márquez, B. Rodríguez-Labajos, et al., "Biodiversity policy beyond economic growth". Conserv. Lett.,2020.

[8] J.C. Costa, D.Z. Sousa, M.A. Pereira and J.M. Stams, "Biomethanation potential of biological and other wastes", In: Gupta VK, Tuohy MG (eds) Biofuel technologies. Springer, Berlin, pp 369-396, 2013, doi: 10.1007/978-3-642-34519-7.

[9] J.C. Hargreaves, M.S. Adl and P.R., "A review of the use of composted municipal solid waste in agriculture". Agriculture, Ecosystems \& Environment, Vol. 123, Issues 1-3, pp. 1- 14., 2008.

[10] H.G Bingemer and P.J. Crutzen, "The production of methane from solid wastes,” J. Geophys. Res.92, 2181-2187, 1987.

[11] H. Heyman, N. Bassuk, J. Bonhotal and T. Walter, "Compost Quality Recommendations for Remediating Urban Soils". Int. J. Environ. Res. Public Health, 16, 3191, 2019.

[12] O. Chukwudi, V.C. Igbokwe V.C., N. Joyce, E. Odimba and I. Lewis, "Composting technology in waste stabilization: On the methods, challenges and future prospects". Journal of Environmental Management, Vol. 190, pp. 140-157, 2017.

[13] A. Cerda, X. Artola, B. Raquel, A. Sánchez, et al., "Composting of food wastes: Status and challenges". Bioresource Technology, Vol. 248, Part A, pp. 57-67, 2018.

[14] M. Salmon, "Composting: The Berkeley Method", 2012.

[15] A.K. Sopiah, W.N. Nazriah, R. Noorazlin and M.D. Norzaidi, "Producing fertilizer from food waste recycling using Berkeley and Bokashi method", Ponte International Scientific Researches Journal 72(4), 2016.

[16] G. Tchobanoglous, H. Theisen, S. Vigil, "Integated solid waste management", Innovative technical and environmental aspects in planning, constructing and operating the sanitary landfill of Larissa, 872-885, Geece, 1993.
[17] F. C. Michel and C.A. Reddy, "Effect of Oxygenation Level on Yard Trimmings Composting Rate, Odor Production and Compost Quality in Bench-Scale Reactors", Compost Sci. Util., 6 (4): 6-14, 1998.

[18] V.K. Sharma, M. Canditelli, F. Fortuna and G. Cornacchia, "Processing of Urban and Agroindustrial Residues by Aerobic Composting", ENEA Research Centre, Department of Environment, Resource, Conservation and Reycling, Trisaia, 23: 209-223, 1996.

[19] T. Meenambal, R. N. Uma and S. Saravannan, "Study on Biodegradation of Fruit Waste Aerobic Composting", Proceedings of the Third International Conference on Environment and Health, Chennai/India, 441-450,2003.

[20] R.T. Haug, "The Practical Handbook of Compost Engineering", Lewis Publishers, London., 1993.

[21] M. Stelmachowski, M. Jastrzebska and R. Zarzycki, "In-Vessel Composting for Utilizing of Municipal Sewage-Sludge", Applied Energy, 75: 249-256, 2003.

[22] Y. Avnimelech, R. Eilat, Y. Porat and P.A. Kottas, "Factors Affecting the Rate Of Windrow Composting In Field Studies" Compost Science \& Utilization, 12(2): 114-118, 2004.

[23] M. Rasapoor, T. Nasrabadi, M. Kamali and H. Hoveidi, "The Effects of Aeration Rate on Generated Compost Quality, Using Aerated Static Pile Method", Waste Management, 29: 570-573, 2008.

[24] A. Richmond, "Outdoor Mass Cultures of Microlagae". (A. Richmond Editor). Handbook of Microlagal Mass Cultures of Microalgae. CRC Press, INC. Boca Raton, Florida, 285-329, 1986.

[25] D. Fox, "Spirulina: Production and Potential", Pub. By Editions Edisud, La Calade, R.N.7, 13090 Aix-enProvince, France, 232 p., 1996.

[26] A., Vonshak, "Outdoor Mass Production of Spirulina: The Basic Concept. (A. Vonshak editor). Spirulina platensis (Arthrospira) Physiology, CellBiology and Biotechnology". Taylor\&Francis Ltd. Printed in Great Britain, pp.79-99, 1997.

[27] J. Bender, J.P. Gould, Y. Vatcharapijam, J.S. Young and P. Philips, "Removal of zinc and manganese from contaminated water with cyanobacteria" Water Environment Research, 66(5): 679-683, 1994.

[28] K. Chojnacka, A. Chojnacki and H. Gorecka, "Biosorption of Cr3+ $\mathrm{Cd} 2+$ and $\mathrm{Cu} 2+$ ions by blue-green algae Spirulina sp.: kinetics, equilibrium and the mechanism of the process", Chemosphere, 59(1): 75-84, 2005.

[29] R. De Phillipis, G. Colica and E. Micheletti, "Exopolysaccharideproducing cyanobacteria in heavy metal removal from water: molecular basis and practical applicability of the biosorption process", Applied Microbiology and Biotechnology, 92: 697-708, 2011.

[30] N.A. Sorkhoh, R.H. Al-Hasan, M. Khanafer and S.S. Radwan, "Establishment of oil-degrading bacteria associated with cyanobacteria in oil-polluted soil", Journal of Applied Microbiology, 78(2): 194-199, 2005.

[31] D.M. Al-Mailem, N.A. Sorkhoh, S. Salamah, M. Eliyas and S.S. Radwan, "Oil-bioremediation potential of Arabian Gulf mud flats rich in diazotrophic hydrocarbon-utlizing bacteria", International Biodeterioration and Biodegradation, 64(3): 218-225, 2010.

[32] C.N. Kenyon, "Fatty acid composition of unicellular strains of bluegreen algae", Journal of Bacteriology, 109(2): 827-834, 1972.

[33] M. Wang, L. Ma, Z. Kong, Q. Wang, L. Fang, D. Liu and Q. Shen, "Insights on the aerobic biodegradation of agricultural wastes under simulated rapid composting conditions", J Clean Prod.; 220:688-97, 2019.

[34] E. Daskalopoulos, O. Badr and S.D. Probert, "Economic and environmental evaluations of waste treatment and disposal technologies for municipal solid waste", Appl Ecol 58:2009-2055, 1999. 